\title{
Science Academies' Refresher Course on Experimental Physics
}

\author{
Sponsored by \\ Indian Academy of Sciences, Bengaluru \\ Indian National Science Academy, New Delhi \\ The National Academy of Sciences, India, Allahabad \\ in collaboration with \\ Department of Physics \\ Mody University of Science and Technology \\ Lakshmangarh, District Sikar (Rajasthan) \\ 23 December 2018 - 7 January 2019
}

\begin{abstract}
A Science Academies' Refresher Course in "Experimental Physics" will be held in the Department of Physics, Mody University of Science and Technology, Lakshmangarh, District Sikar (Rajasthan), from 23 December 2018 to 07 January 2019 for the benefit of faculty involved in teaching undergraduate and postgraduate courses in Physics. Participants in this course will gain hands on experience with about 25 experiments designed by Professor R Srinivasan, the Course Director, Indian Academy of Sciences.
\end{abstract}

Mody University of Science and Technology (MUST) is covered under section 2(f) of the UGC act, 1956 and is empowered to award degrees specified by UGC under section 22 of UGC act, 1956. The University is awarded as "Best Private Women's University in Asia" (ASSOCHAM and The Education Post, 2017). The Department of Physics offers BSc (Hon) Physics and MSc Physics. Department has state-ofthe-art- laboratories equipped with latest instruments enabling them getting involved in most up-to-date experiments and research activities.

Professor R Srinivasan has conducted such Refresher course in Experimental Physics in more than 75 institutions so far including universities, autonomous colleges, and advanced scientific institutions involved in education. The Course will enable the participants, through lectures and laboratory sessions, to enhance their skills in experimental physics and facilitate them to introduce the experiments in their respective curricula. UGC has approved two weeks Refresher Courses of good standing for promotion, vide notification: F31/2009 dated 30 June 2010.

Applications are invited from teachers with experience in teaching undergraduate and postgraduate courses in Physics. III year BSc and I year MSc Physics students with keen interest in Experimental Physics may also apply. The number of seats will not exceed 34. Selected participants will be provided with roundtrip bus/train (III AC) fare by the shortest route and local hospitality during the course in addition to course material.

Interested applicants must submit their application ONLINE by clicking apply here or copy and paste following link in web browser:

http://web-japps.ias.ac. in: 8080/Refreshcourse/MODY.jsp

A copy of the application form signed by the applicant should also be sent by Post to The Course Coordinator. In case of teachers, the form must also be signed and stamped by the Head of the applicant's institution stating that leave will be sanctioned if the applicant is selected for the Course. A recommendation letter from a teacher is essential for student applicants. Scanned copies of the duly signed documents sent by email will also be accepted.

Applications may be sent to: Dr Brajraj Singh, Course Coordinator, Refresher Course in Experimental Physics, Department of Physics, Mody University of Science and Technology, Lakshmangarh 332311, District Sikar (Rajasthan).

Email:sbrajraj@gmail.com, Phone:09983198078Email:rakheechaudhary@gmail.com,Phone:09414209998L

Last date for the receipt of applications: 24 November 2018

Selected participants will be informed by: 30 November 2018 